\title{
Thyroid Transcription Factor 1
}

National Cancer Institute

\section{Source}

National Cancer Institute. Thyroid Transcription Factor 1. NCI Thesaurus. Code C73445.

Thyroid transcription factor 1 (371 aa, $\sim 39 \mathrm{kDa}$ ) is encoded by the human NKX2-1 gene.

This protein is involved in transcriptional regulation. 